\title{
FINANCIAL RATIO ANALYSIS OF BANKING LIQUIDITY LEVEL: A CASE STUDY AT SOE PERSERO BANKS IN INDONESIA
}

\author{
Utomo Ely Sapto* \\ Graduate Program, University of Gunadarma, Jakarta, Indonesia \\ Fernandez Mahaza Dwi Christian, Lecturer \\ University of Gunadarma, Jakarta, Indonesia \\ *E-mail: fmahazadc@yahoo.co.id \\ ORCID 0000-0003-0004-1825
}

\begin{abstract}
Bigger CAR indicates that a bank has sufficient capital to support needs and to bear risks including credit risk. By having large capital, a bank can channel more credit. If credit increases, it will automatically increase the LDR. This research is a case study at SOE Persero Banks in Indonesia. The data used in this research are secondary data. The research population is the financial statements of Persero banks which include PT Bank Negara Indonesia Tbk, PT Bank Rakyat Indonesia Tbk, PT Bank Mandiri Tbk, and PT Bank Tabungan Negara Tbk; within a research period of 5 years from 2010-2014. Research sampling was carried out using the purposive sampling method. The method included the classical assumption test, multiple linear regression analysis and hypothesis testing. The research findings indicated that CAR and NPL partially have significant effect on LDR. Moreover, NIM partially has no significant effect on LDR. Then, CAR, NPL, and NIM simultaneously have significant effect on LDR.
\end{abstract}

\section{KEY WORDS}

Capital adequacy ratio, non-performing loan, net interest margin, loan to deposit ratio.

National development of a nation includes economic development. The economic development of a country is very dependent on the development and contribution of the banking sector because the role of financial institutions such as banking is very essential to finance ongoing economic development. Indonesia's economic performance, towards the end of 2008, was marked by the deterioration of the global economy in the domestic economy (Sudiyatno \& Suroso, 2010). The continued weakening of the global economy and the decline in commodity prices have an effect on Indonesia's exports which in turn has an impact on the declining balance of payments and exchange rates on the financial markets. The global financial crisis has caused turmoil in the money market, foreign exchange market and bond market.

However, in such conditions, Indonesia is not in the worst condition compared to other countries. Generally, on Indonesia's macroeconomic performance, the level of economic growth can be considered to be quite good. The resilience of the domestic financial system, particularly the banking industry, is also quite strong as a result of efforts to strengthen the banking system carried out since the crisis in 1998. In addition, the banking sector has also improved itself by increasing discipline and promoting the principle of prudence.

Banks, as trust institutions/ community intermediary institutions and part of the monetary system, have a strategic position to support economic development. Bank management is required to always maintain a balance between maintaining adequate levels of liquidity and high bank profitability and meeting capital requirements. The bank's health maintenance is carried out by maintaining its liquidity so that the bank can fulfill its obligations to all parties who withdraw their deposits at any time.

In carrying out its operations, bank certainly involve in a variety of risks. The bank's business risk is a level of uncertainty regarding an expected outcome (Permono, 2000). Non- 
Performing Loans (NPL) are financial ratios related to credit risk. According to Ali (2006), credit risk is the risk of possible bank losses as a result of non-repayment of loans given by banks to debtors. Non-Performing Loans are a comparison between the total non-performing loans and total loans given to debtors. Banks have a high NPL if they have problem loans greater than the amount of credit given to debtors. Every service offered by the bank is unique. One of the main concerns of the bank is the level of risk the product has. Moreover, regarding to the credit channeled by the bank, it is possible that there is a risk of default or what we usually call by NPL (Non-Performing Loan) (Firmansyah, 2014).

LDR can be a leading indicator in assessing banking intermediation functions. The higher the distribution of TPF loans, the function of banking intermediation will run very well. On the contrary, the low credit distribution using TPF shows that the intermediation function did not run smoothly because deposits were not channeled back to the community. Rather, it is used for other purposes; for example, to buy Bank Indonesia Certificates, inventory, and so on. LDR is also one indicator in assessing the soundness of banks. Bank Indonesia provides a health assessment of banks in Indonesia based on several aspects of liquidity in which the LDR is one indicator.

On the one hand, the higher LDR of banks will provide greater risk for the failure of loans that have been channeled to the public in the future. However, on the other hand, it can increase the bank's income because each loan will provide income in the form of interest. The difference between interest income and bank interest expense is reflected in the Net Interest Margin ratio (Nguyen, 2012). NIM is used to measure the ability of bank management to manage their productive assets in generating net interest income. This ratio shows the ability of banks to obtain operating income from funds placed in the form of loans (credit). A high NIM indicates that banks are increasingly effective in placing earning assets in the form of loans. The standard, that is set by Bank Indonesia for the NIM ratio is $6 \%$ and above; the greater the ratio, the higher interest income on productive assets managed by the bank. Thus, the possibility for a bank to be in a problematic condition is getting smaller.

The reason for choosing the Loan to Deposit Ratio (LDR) as the dependent variable is that it is in accordance with Bank Indonesia Circular Letter No.6/23/DPNP May 31, 2004. It states that the LDR ratio is calculated from the distribution of loans to third parties (not including bank) with deposits including deposits, savings and time deposits (not including interbank). The LDR value of each Persero ${ }^{1}$ bank from 2010-2014 underwent a change in each period. It is due to the instability of the bank's growth rate in the long run so that predictions are needed on the factors affecting the Loan to Deposit Ratio (LDR).

If the Capital Adequacy Ratio (CAR) is good, the community will be interested in taking credit and the bank has a reserve fund it faces a problem with bad credit. Non-Performing Loan (NPL) reflects the ability of banks to manage credit risk arising from various incoming loans classified as problem loans (Bin, 2005). The greater the problem loans, the smaller the credit that is channeled by banks to the community. Good or poor bank intermediation will have an impact on interest income that will be experienced by the bank. The better the bank intermediation, the better the Net Interest Margin (NIM) of the bank concerned. Do Capital Adequacy Ratio (CAR), Non-Performing Loan (NPL), and Net Interest Margin (NIM) have effect on the Loan to Deposit Ratio (LDR)?

\section{METHODS OF RESEARCH}

This research applies quantitative method by using a combination of cross section data and time series (Amihud, 2002). The data were obtained from Bank Indonesia and other sources that support the fulfillment of data. The data processing applied several methods including hypothesis testing, multiple regression coefficient analysis both simultaneously ( $F$ test) and partially (t test), and the results of multiple regression both overall and partial. To support these findings, the classical assumption test was conducted to see whether the

\footnotetext{
${ }^{1}$ Persero is one of the Business Entities managed by the State or Region.
} 
independent variables have met the requirement so that the results of the hypothesis testing are not biased.

The research population is the financial statements of 4 Persero banks consisting of PT Bank Negara Indonesia Tbk, PT Bank Rakyat Indonesia Tbk, PT Bank Mandiri Tbk, and PT Bank Tabungan Negara Tbk with a 5-year research period from 2010-2014. Research sampling was carried out by using a purposive sampling method because the samples must have criteria: they are go-public Persero Banks listed on the Indonesia Stock Exchange and have complete financial reports for the period 2010-2014. Thus, the number of observations is 80 which are obtained from $4 \times 20$ (the multiplication between the number of banks and the period of observation) (Tongco, 2007).

To determine the effects of CAR, NPL, and NIM on the LDR, multiple regression analysis was applied. The use of multiple regression analysis aims to make a mathematical model of the effects of CAR, NPL, and NIM on the LDR. Based on the model, we can determine the effect of CAR, NPL, and NIM on the LDR. The general form of multiple linear regression equations is as follows:

$$
Y=\alpha+b_{1} x_{1}+b_{2} x_{2}+b_{3} x_{3}+\varepsilon
$$

Where: $\alpha=$ Constant Regression Equations; $x_{1}=$ Capital Adequacy Ratio (CAR); $x_{2}=$ NonPerforming Loan (NPL); $x_{3}=$ Net Interest Margin (NIM); $Y=$ Loan to Deposit Ratio (LDR); $b_{1}-b_{3}=$ Regression Coefficient; $\varepsilon=$ Random Error.

In the Multiple Regression Test, the Determination Coefficient is used to determine the percentage of contributions to the simultaneous effect of independent variables on the rise or fall of the dependent variable. For this reason, the numbers in the Model Summary Table $\mathrm{R}^{2}$ are the comparisons between the $Y$ variations explained by $X_{1}$ and $X_{2}$ simultaneously compared to the total variation $Y$. In addition to $X_{1}$ and $X_{2}$, all variables outside the model contained in $Y$ are entered into in the model. Then, the value $R^{2}$ is 1 . It means that all $Y$ variations can be explained by the explanatory variables entered in the model.

There is no exact measure of how large $R^{2}$ is to determine that a variable choice is correct. If $\mathrm{R}^{2}$ gets bigger or closer to 1 , the model is more precise. For cross-section survey data which is obtained from many respondents at the same time, the value of $R^{2}=0.2$ or 0.3 is good enough. The greater the $n$ (sample size), the $R^{2}$ value tends to be smaller. On the other hand, if $n$ gets smaller then $\mathrm{R}^{2}$ will tend to be greater. This is due to the relatively small variation of data in the time series data which consists of only one unit of analysis.

The $F$ test is carried out to find out whether or not the independent variables $\left(X_{1}, X_{2}\right.$, $\left.\ldots ., X_{n}\right)$ in the regression model have a significant effect on the dependent variable $(Y)$. The significance of the ANOVA table shows the magnitude of the probability number or significance in the ANOVA calculation. The values are used for the service analysis model in which a number of variables $X$ affects the $Y$ variable. A good probability value to be used as a regression model must be $<0.05$. This value can be seen in the Sig column. If Sig. $<0.05$, the analysis model is considered feasible. If Sig. $>0.05$, the analysis model is considered not feasible.

The hypothesis for this ANOVA test includes:

- If the Sig. value is $<0.05 \mathrm{H}_{0}$ is rejected;

- If the Sig. value is $>0.05 \mathrm{H}_{\mathrm{a}}$ is accepted.

The $t$ test is conducted to determine whether or not the independent variables $\left(X_{1}, X_{2}\right.$, $\left.\ldots ., X_{n}\right)$ in the regression model partially have significant effect on the dependent variable $(Y)$. The independent variables can explain the dependent variable which can be seen from each of the independent variables. If the significance value is 0.000 then it is very significant. The following criteria are used in SPSS testing:

- If significant value of research findings is $<0.05$; the correlation between variables is significant;

- If significant value of research findings is $>0.05$; the correlation between variables is not significant. 


\section{RESULTS OF STUDY}

Regression analysis is used to analyze the effect of independent variables on the dependent variable. In this research, multiple regression analysis was used to analyze the effects of the Capital Adequacy Ratio (CAR), Non-Performing Loans (NPL), and Net Interest Margin (NIM) on the Loan to Deposit Ratio (LDR). The coefficient of the independent variable in the multiple regression equation will be interpreted using Standardized Beta Coefficients. Statistical calculations in multiple linear regression analysis of this research was carried out with the help of computer program SPSS for Windows version 19. The results of data processing using the SPSS program are then explained in Table 2 below.

Table 1 - Results of Linear Regression Test

Coefficients $^{a}$

\begin{tabular}{|c|c|c|c|c|c|c|c|}
\hline \multirow{2}{*}{ Model } & \multicolumn{2}{|c|}{ Unstandardized Coefficients } & \multirow{2}{*}{$\frac{\text { Standardized Coefficients }}{\text { Beta }}$} & \multirow{2}{*}{$\mathrm{t}$} & \multirow{2}{*}{ Sig. } & \multicolumn{2}{|c|}{ Collinearity Statistics } \\
\hline & $B$ & Std. Error & & & & Tolerance & VIF \\
\hline (Constant) & 41.552 & 17.447 & & 2.382 & .020 & & \\
\hline $\mathrm{X} 1$ & 2.000 & .955 & .217 & 2.093 & .040 & .971 & 1.030 \\
\hline $\mathrm{X} 2$ & 5.138 & 1.238 & .442 & 4.150 & .000 & .915 & 1.093 \\
\hline X3 & .127 & .921 & .015 & .138 & .890 & .934 & 1.071 \\
\hline
\end{tabular}

a. Dependent Variable: $Y$

Source: Processing results from SPSS 19.

Based on the table above, the regression equation is:

$$
Y=41.552+2.00 X_{1}+5.138 X_{2}+0.127 X_{3}
$$

Where: $Y=$ Loan to Deposit Ratio (LDR); $X_{1}=$ Capital Adequacy Ratio (CAR); $X_{2}=$ NonPerforming Loan (NPL); $X_{3}=$ Net Interest Margin (NIM).

The results of the analysis are interpreted as follows:

- The constant of 41.552 shows that if the Capital Adequacy Ratio (CAR), NonPerforming Loan (NPL), and Net Interest Margin (NIM) are zero, the Loan to Deposit Ratio (LDR) is 41.552;

- Capital Adequacy Ratio (CAR) $\left(\mathrm{X}_{1}\right)$ of 2.00 means that if the CAR variable increases by one unit then the Loan to Deposit Ratio (LDR) variable will increase by 2.00 assuming that the other independent variables from the regression model are fixed;

- Non-Performing Loans (NPL) $\left(\mathrm{X}_{2}\right)$ of 5.138 means that if the NPL variable increases by one unit then the Loan to Deposit Ratio (LDR) variable will increase by 5.138 assuming that the other independent variables from the regression model are fixed;

- Net Interest Margin (NIM) (X3) of 0.127 means that if the NIM variable increases by one unit of then the Loan to Deposit Ratio (LDR) $(\mathrm{Y})$ variable will increase by 0.127 assuming that the other independent variables from the regression model are fixed.

The determination coefficient is used to determine how much the correlation of several variables in a clearer sense. The determination coefficient will explain how much change or variation in a variable can be explained by changes or variations on other variables. This coefficient value is between 0 and 1 . If the results are closer to the number 0 , the ability of the independent variables to explain variable variations is very limited. On the other hand, if the results are closer to 1, it means that the independent variables provide almost all the information needed to predict variations of the dependent variable.

Based on Table 2, the Adjusted R Square value is 0.179. Adjusted R Square is also known as the determination coefficient so that $17.9 \%$ shows that the percentage contribution of the independent variables Capital Adequacy Ratio (CAR), Non-Performing Loans (NPL), and Net Interest Margin (NIM)) to the dependent variable Loan to Deposit Ratio (LDR) is $17.9 \%$, while the remaining $82.1 \%$ is affected or explained by other variables not included in this research. 
The Standard Error of the Estimate is a measure of the number of errors in the regression model in predicting the value of $\mathrm{Y}$. The regression results obtain a value of 12.641, which means that the prediction of the Loan to Deposit Ratio (LDR) is 12.641 units.

Model Summary

$$
\text { Table } 2 \text { - Test Results of Determination Coefficient }\left(R^{2}\right)
$$

\begin{tabular}{|c|c|c|c|c|c|}
\hline Model & $\mathrm{R}$ & $\mathrm{R}$ Square & Adjusted R Square & Std. Error of the Estimate & Durbin-Watson \\
\hline 1 & $.459^{\mathrm{a}}$ & .211 & .179 & 12.641 & 2.544 \\
\hline
\end{tabular}

a. Predictors: (Constant), X3, X1, X2

b. Dependent Variable: $Y$

Source: Processing results from SPSS 19

According to Sugiyono (2007), the $F$ test is a test tool that aims to find out whether there is a simultaneous and significant effect between the independent variables consisting of the Capital Adequacy Ratio (CAR) $\left(\mathrm{X}_{1}\right)$, Non-Performing Loans (NPL) $\left(\mathrm{X}_{2}\right)$ and Net Interest Margin (NIM) $\left(\mathrm{X}_{3}\right)$ and the dependent variable Loan to Deposit Ratio (LDR) (Y). In addition, this model aims to determine whether the independent variables $\left(X_{1}, X_{2} \ldots . X_{n}\right)$ simultaneously have significant effects on the dependent variable $(Y)$. The basis of the criteria for decision making is carried out through significant probability values as follows:

- If the probability value is $f>0.05$ then $\mathrm{H}_{0}$ is accepted and $\mathrm{H}_{a}$ is rejected;

- If the probability value is $f<0.05$, then $H_{0}$ is rejected and $H_{a}$ is accepted.

The results of the $\mathrm{F}$ test can be seen in the following table:

Table 3 - F Test Results

ANOVA $^{b}$

\begin{tabular}{|c|c|c|c|c|c|}
\hline Model & Sum of Squares & df & Mean Square & $\mathrm{F}$ & Sig. \\
\hline $\begin{array}{cc} & \text { Regression } \\
1 & \text { Residual } \\
\text { Total }\end{array}$ & $\begin{array}{c}3239.490 \\
12144.060 \\
15383.550\end{array}$ & $\begin{array}{c}3 \\
76 \\
79\end{array}$ & $\begin{array}{c}1079.830 \\
159.790\end{array}$ & 6.758 & $.000^{\mathrm{a}}$ \\
\hline
\end{tabular}

a. Predictors: (Constant), $X_{3}, X_{1}, X_{2} ; b$. Dependent Variable: $Y$.

Source: Processing results from SPSS 19

Based on table 3, the $F$ test produces the Sig. 0.000 or $<0.05$ which means that $\mathrm{H}_{0}$ is rejected. Therefore, it is concluded that simultaneously there are significant effects between the variables of Capital Adequacy Ratio (CAR), Non-Performing Loans (NPL), and Net Interest Margin (NIM) on the Loan to Deposit Ratio (LDR). According to Kuncoro (2000), ttest is used to determine whether the independent variables Capital Adequacy Ratio (CAR), Non-Performing Loans (NPL), and Net Interest Margin (NIM) partially have significant effect on the dependent variable Loan to Deposit Ratio (LDR) with a significant level of 0.05 or $5 \%$. Decision making can also be carried out by looking at the probability values. If the probability value is smaller than 0.05 then $\mathrm{H}_{0}$ is rejected while if the probability is greater than 0.05 then $\mathrm{H}_{0}$ is accepted. The t-test results can be seen in the following table:

Table 4 - t-Test Results

Coefficients $^{a}$

\begin{tabular}{|c|c|c|c|c|c|c|c|}
\hline \multirow{2}{*}{ Model } & \multicolumn{2}{|c|}{ Unstandardized Coefficients } & \multirow{2}{*}{$\frac{\text { Standardized Coefficients }}{\text { Beta }}$} & \multirow{2}{*}{$t$} & \multirow{2}{*}{ Sig. } & \multicolumn{2}{|c|}{ Collinearity Statistics } \\
\hline & $\mathrm{B}$ & Std. Error & & & & Tolerance & VIF \\
\hline (Constant) & 41,552 & 17,447 & & 2,382 &, 020 & & \\
\hline $\mathrm{X} 1$ & 2,000 & ,955 & ,217 & 2,093 &, 040 & ,971 & 1,030 \\
\hline $\mathrm{X} 2$ & 5,138 & 1,238 & ,442 & 4,150 &, 000 & ,915 & 1,093 \\
\hline $\mathrm{X} 3$ & 127 & ,921 & 015 &, 138 &, 890 & ,934 & 1,071 \\
\hline
\end{tabular}

a. Dependent Variable: $Y$.

Source: Processing results from SPSS 19. 
Capital Adequacy Ratio (CAR) toward Loan to Deposit Ratio (LDR). Based on table 4, the test results obtained $t=2.093$ for the Capital Adequacy Ratio (CAR) variable with a significance value of $0.040<0.05$. The significance value is below 0.05 which means that Capital Adequacy Ratio (CAR) has a significant effect on the Loan to Deposit Ratio (LDR). It means that hypothesis 1 is accepted.

Non-Performing Loans (NPL) toward Loan to Deposit Ratio (LDR). Based on table 4, the test results obtained $t=4.150$ for the Non-Performing Loan (NPL) variable with a significance value of $0.000<0.05$. The significance value is below 0.05 which means that Non-Performing Loan (NPL) has a significant effect on the Loan to Deposit Ratio (LDR). It means that hypothesis 2 is accepted.

Net Interest Margin (NIM) toward Loan to Deposit Ratio (LDR). Based on table 4, the test results obtained $t=0.138$ for the Net Interest Margin (NIM) variable with a significance value of $0.000<0.05$. The significance value is above 0.05 which means that it indicates that Net Interest Margin (NIM) does not have a significant effect on the Loan to Deposit Ratio (LDR). It means that hypothesis 3 is not accepted.

\section{DISCUSSION OF RESULTS}

Determining the Effect of Capital Adequacy Ratio (CAR) on the Loan to Deposit Ratio $(L D R)$. The results of partial test (t-test) between CAR and LDR variables show the $t$ calculate value of 2.093 , the regression coefficient of 2.000 , and the probability value of 0.040 which is smaller than 0.05 . It means that CAR has a significant effect on the LDR of SOE Persero Banks. Thus, the hypothesis stating that CAR ratio has a significant effect on the LDR is accepted.

The research findings showed that a large CAR indicates that the bank has sufficient capital to support its needs and bears the risks including credit risk. By having large capital, banks can channel more credit. In line with the increased credit, it will increase the LDR. The main function of bank capital is to meet minimum needs and support assets that contain or produce risks; for instance, credit. In other words, Capital Adequacy Ratio (CAR) is the level of capital adequacy of the bank in providing funds and business development needs and accommodating the risk of fund loss caused by bank operations. The level of capital adequacy of a bank is very important in channeling credit to the community. Reviewing the condition of the CAR at each SOE Persero Bank from 2010 to 2014, each bank has provided a minimum capital of more than $8 \%$. This allows banks to offer more credit. This research is supported by the findings of previous research conducted by Nandadipa (2010) and Granita (2011) which showed that CAR has a significant effect on LDR.

Determining the Effect of Non-Performing Loan (NPL) on the Loan to Deposit Ratio $(L D R)$. The results of partial test (t-test) between NPL and LDR variables show the t calculate value of 4.150 , the regression coefficient of 5.138 , and the probability value of 0.000 which is smaller than 0.05. It means that NPL has a significant effect on the LDR of SOE Persero Banks. Thus, the hypothesis stating that NPL ratio has a significant effect on the LDR is accepted.

The research findings showed that fewer Non-Performing Loans make banks more willing to increase their credit distribution. Moreover, if third party funds can be achieved optimally, the liquidity of a bank will not be disrupted. Therefore, Non-Performing Loans that are getting smaller are reflected in the NPL value. The credit that banks can channel to the community is getting bigger while keeping in mind that credit risk can arise. NPL is an opportunity to obtain income from credit. Therefore, it can increase profits and the ability to provide credit. Reviewing the condition of the average NPL at SOE Persero Banks in 20102014 which is always below the $5 \%$, it is in accordance with Bank Indonesia regulations which require banks to maintain the NPL level below 5\%. From 2010 to 2013, the NPL declined and the value was stable in 2014. It shows that credit risk has decreased well every year. These research findings are also supported by the findings of research conducted by Nugraha (2015), Granita (2011), Utari and Haryanto (2011), and Nandadipa and Prasetiono (2010) which showed that NPL has a significant effect on LDR. 
Determining the Effect of Net Interest Margin (NIM) on the Loan to Deposit Ratio $(L D R)$. The results of partial test (t-test) between NIM and LDR variables show the t calculate value of 0.138 , the regression coefficient of 0.127 , and the probability value of 0.890 which is greater than 0.05. It means that NIM does not have significant effect on the LDR of SOE Persero Banks. Thus, the hypothesis stating that NIM ratio has a significant effect on the LDR is rejected.

The research findings showed that the declining NIM reflects the ineffectiveness of banks in placing earning assets in the form of loans. NIM is a comparison between net interest income (interest income and interest expense) and average earning assets. The NIM has an effect on bank intermediation because the bank's good intermediation will have an impact on the interest income that will be obtained by the bank. This makes the SOE Persero Banks pay more attention to measuring the ability of bank management in managing their productive assets in order to generate net interest income. To make net interest in accordance with the target, namely to provide an increase in the acquisition of net income, it needs to be considered to utilize its productive assets appropriately. The average condition of NIM at SOE Persero Banks in 2010-2011 is quite good, because it has a value above 6\%; the value set by Bank Indonesia. However, in 2012 it decreased which made the value of NIM below the $6 \%$ value. Yet, in the following year the year 2013 it experienced an increase of more than $6 \%$, before finally in 2014 the net interest value had decreased again below $6 \%$. It makes SOE Persero Banks improving the ability of bank management to manage productive activities in order to achieve net interest that is in accordance with the target. These research findings are supported by the findings of the research conducted by Ramadhoni Eka Nugraha (2014) who found that NIM has no significant effect on LDR.

Determining the Effect of Capital Adequacy Ratio (CAR), Non-Performing Loan (NPL), and Net Interest Margin (NIM) on the Loan to Deposit Ratio (LDR). The simultaneous test results ( $F$ test) between the CAR, NIM, and NPL variables with the LDR variable indicate the sig. value of 0,000 or $<0.05$. It means that simultaneously CAR, NIM, and NPL have a significant effect on LDR of SOE Persero banks. Thus, the hypothesis stating that CAR, NIM, and NPL ratios have significant effect on LDR can be accepted.

The findings showed that simultaneously CAR, NPL, NIM have a good effect on the LDR. It means that the amount of capital is good enough to support their needs and to bear the risks including credit risk. By having large capital, a bank can channel more credit. Increased credit will increase the LDR. Supported by NPLs, the lack of non-performing loans made banks more willing to increase their credit distribution. In addition, if third party funds can be achieved optimally, the liquidity of a bank will not be disturbed. Therefore, the bank gets the opportunity from the credit it provides. Although the NIM has decreased, it shows that banks are less effective in placing earning assets in the form of credit, but this can be covered by good capital adequacy and lack of problem loans. It makes the bank able to increase its credit distribution which eventually could increase the LDR. However, the measurement of bank management in managing earning assets in order to generate net interest income is still carried out, so that the net interest is in accordance with the target; that is giving an increase in the acquisition of net income. It needs to be considered to make banks able to utilize their productive assets well. These research findings are supported by the findings of research conducted by Nugraha (2014), which found that CAR, NPL, and NIM simultaneously have a significant effect on LDR.

\section{CONCLUSION}

Based on data analysis and discussion of the research findings, the following conclusions can be drawn:

Based on the research findings, the Capital Adequacy Ratio (CAR), Non-Performing Loans (NPL), and Net Interest Margin (NIM) variables simultaneously have a significant effect on the Loan to Deposit Ratio (LDR). It means that any changes that occur in the independent variables CAR, NPL, and NIM simultaneously or jointly will affect the LDR at SOE Persero banks in Indonesia. 
Partially, the Capital Adequacy Ratio (CAR), Non-Performing Loans (NPL), and Net Interest Margin (NIM) variables have an effect on the Loan to Deposit Ratio (LDR) and the most dominant variables affecting the LDR based on the research findings are as follows:

- CAR variable has a significant effect on the LDR at SOE Persero banks in Indonesia;

- NPL variable has a significant effect on the LDR at SOE Persero banks in Indonesia;

- NIM variable does not have significant effect on the LDR at SOE Persero banks in Indonesia.

\section{REFERENCES}

1. Ali, M. (2006). Manajemen Risiko - Strategi Perbankan dan Dunia Usaha Menghadapi Tantangan Globalisasi Bisnis. Jakarta: Rajawali Pers

2. Amihud, Y. (2002). Illiquidity and stock returns: cross-section and time-series effects. Journal of financial markets, 5(1), 31-56.

3. Bin, L. (2005). An Empirical Study of the Impact of Capital Adequacy Ratio on Banks Loans [J]. Journal of Finance, 11, 003.

4. Firmansyah, I. (2014). Determinant of non-performing loan: The case of Islamic bank in Indonesia. Buletin Ekonomi Moneter dan Perbankan, 17(2), 241-258.

5. Granita, J. K. (2011). Influence analysis of deposits, CAR, ROA, NPL, NIM, BOPO, interest rates, inflation and exchange rate against LDR (studies in national private exchange bank 2002-2009 period) (Doctoral dissertation, Thesis in Bachelor Program Economic Faculty Diponegoro University, Semarang).

6. Kuncoro, Mudrajad. 2000. Ekonomi Pembangunan: Teori, Masalah dan Kebijakan, UPP AMP YKPN.

7. Nandadipa, S., \& PRASETIONO, P. (2010). Analisis Pengaruh CAR, NPL, Inflasi, Pertumbuhan DPK, dan Exchange Rate terhadap LDR (Studi Kasus pada Bank Umum di Indonesia Periode 2004-2008) (Doctoral dissertation, Universitas Diponegoro).

8. Nandadipa, S., \& PRASETIONO, P. (2010). Analisis Pengaruh CAR, NPL, Inflasi, Pertumbuhan DPK, dan Exchange Rate terhadap LDR (Studi Kasus pada Bank Umum di Indonesia Periode 2004-2008) (Doctoral dissertation, Universitas Diponegoro).

9. Nguyen, J. (2012). The relationship between net interest margin and noninterest income using a system estimation approach. Journal of Banking \& Finance, 36(9), 2429-2437.

10. Nugraha, R. E. (2015). Analisis Pengaruh Capital Adequacy Ratio (Car), Non Performing Loan (Npl), Biaya Operasional Pendapatan Operasional (Bopo), Return On Asset (Roa) Dan Net Interest Margin (Nim) Terhadap Loan To Deposit Ratio (Ldr)(Studi Empiris Pada Perbankan Syariah Di Indonesia Periode 2010-2012) (Doctoral dissertation, Universitas Muhammadiyah Surakarta).

11. Permono, I.S. dan Darmawan (2000). Analisis Efisiensi Industri Perbankan di Indonesia (Studi Kasus Bank-bank Devisi di Indonesia Tahun 1991-1996), Jurnal Ekonomi dan Bisnis Indonesia (JEBI) Volume 15, No.1, 2000, Yogyakarta. PT Raja Grafindo Persada.

12. Sudiyatno, B., \& Suroso, J. (2010). Analisis Pengaruh Dana Pihak Ketiga, BOPO, CAR dan LDR terhadap Kinerja Keuangan pada Sektor Perbankan yang Go Public di Bursa Efek Indonesia (BEI)(Periode 2005-2008). Dinamika Keuangan dan Perbankan, 2(2).

13. Sugiyono. 2007. Statistika Untuk Penelitian. Bandung: Alfabeta.

14. Tongco, M. D. C. (2007). Purposive sampling as a tool for informant selection. Ethnobotany Research and applications, 5, 147-158.

15. Utari, M. P., \& Haryanto, A. M. (2011). Analisis Pengaruh CAR, NPL, ROA, dan BOPO terhadap LDR (Studi Kasus pada Bank Umum Swasta Nasional Devisa di Indonesia Periode 2005-2008) (Doctoral dissertation, Universitas Diponegoro). 